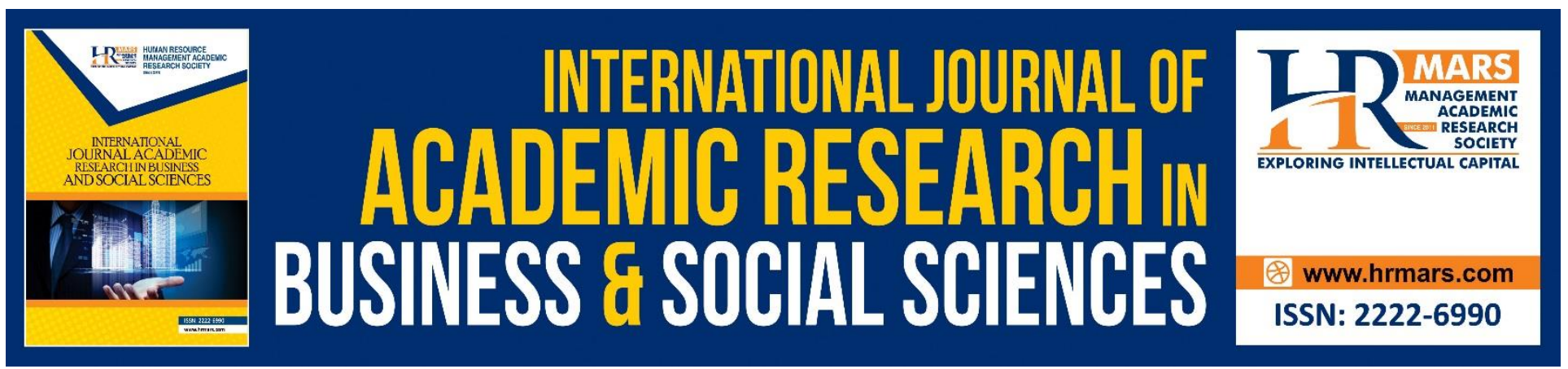

\title{
A Determinant Method of Data Validity Based On Mutawatir Concept in 'IIm Al-Qira'at
}

Nur Sakiinah binti Ab Aziz, Mohd Shukri Hanapi

To Link this Article: http://dx.doi.org/10.6007/IJARBSS/v8-i10/4725

DOI: $10.6007 /$ IJARBSS/v8-i10/4725

Received: 27 Sept 2018, Revised: 21 Oct 2018, Accepted: 27 Oct 2018

Published Online: 30 October 2018

In-Text Citation: (Aziz \& Hanapi, 2018)

To Cite this Article: Aziz, N. S. binti A., \& Hanapi, M. S. (2018). A Determinant Method of Data Validity Based On Mutawatir Concept in 'Ilm Al-Qira'at. International Journal of Academic Research in Business and Social Sciences, 8(10), 202-211.

\section{Copyright: (C) 2018 The Author(s)}

Published by Human Resource Management Academic Research Society (www.hrmars.com)

This article is published under the Creative Commons Attribution (CC BY 4.0) license. Anyone may reproduce, distribute, translate and create derivative works of this article (for both commercial and non-commercial purposes), subject to full attribution to the original publication and authors. The full terms of this license may be seen

at: http://creativecommons.org/licences/by/4.0/legalcode

Vol. 8, No. 10, 2018, Pg. 202 - 211

http://hrmars.com/index.php/pages/detail/IJARBSS

JOURNAL HOMEPAGE

Full Terms \& Conditions of access and use can be found at http://hrmars.com/index.php/pages/detail/publication-ethics 


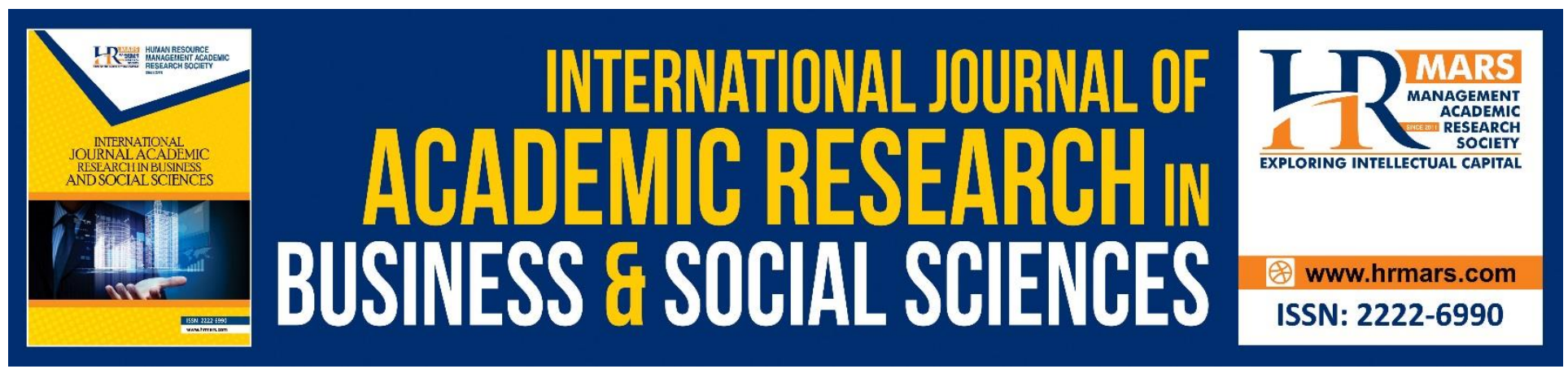

\title{
A Determinant Method of Data Validity Based On Mutawatir Concept in 'IIm Al-Qira'at
}

\author{
Nur Sakiinah binti Ab Aziz ${ }^{1}$, Mohd Shukri Hanapi² \\ ${ }^{1}$ Faculty of Islamic Contemporary Studies, Universiti Sultan Zainal Abidin (UniSZA), 21300 Kuala \\ Terengganu, Terengganu. \\ ${ }^{2}$ Centre for Islamic Development Management Studies (ISDEV), University Sains Malaysia, 11800 \\ Minden, Penang, Malaysia.
}

\begin{abstract}
This paper has two principal purposes. First, to identify the determinant method of data validity in common research methodology. Second, to analyze the determinant method of data validity based on mutawatir concept in 'Ilm al-Qira'at. Mutawatir concept is one of the most important condition in 'Ilm al-Qira'at to determine the authenticity of a qira'at. A qira'at which do not meet the conditions set out in the concept mutawatir cannot be considered a qira'at mutawatirat. If these requirements are not met, then a qira'at less and are not counted as one of the recitation of the Qur'an. Based on the concept of accuracy of mutawatir, he views can be used to determine the data either investigation. Thus, there are two issues that arise which is whether the flaws contained in the means of determining common investigation data conference? Is there a corresponding concept indeed became one of the means of determining the data either investigation? To answer both of these questions, this paper uses the method of content analysis and library. Based on goals and issues raised, formulated that the elements contained in the concept of necessity as the number of narrators mutawatir and narrators' characteristics allow the concept of mutawatir according as one of the means the determination of the Conference data.
\end{abstract}

Keywords: Data Validity, Mutawatir, Qira'at, Rules, Islamic Research Methodology.

\section{Introduction}

The method to determinant data validity is one of the most important method to ensure that data has been collected to comply and achieve researchers' goals (Gay \& Air Asian, 2000; Susan Kimball, 1990). The data validity refers to how an idea of reality fit/suitable to applied in actual reality (Neuman, 2007).

This paper aims to identify the determinant method of validity in common research methodology and subsequently analyze this determinant method based on mutawatir concept in 'Ilm al-Qira'at. Term of mutawatir is widely used in the Islamic traditional knowledge especially in " IIm al-Hadith and 'IIm 
INTERNATIONAL JOURNAL OF ACADEMIC RESEARCH IN BUSINESS AND SOCIAL SCIENCES Vol. 8, No. 10, Oct. 2018, E-ISSN: 2222-6990 @ 2018 HRMARS

al-Qira'at. This paper focuses on the mutawatir concept in 'Ilm al-Qira'at because through condition of mutawatir, verse or ayah of the Qur'an can be verified as authentic verse and recognized as one of the revelations from God.

Therefore, the identification of the determinant method of data validity in common research methodology should be carried out. Through this identification, researcher can acknowledge weaknesses and deficiencies found in the common determinant method of data validity. In addition, the analysis of the mutawatir concept in 'IIm al-Qira'at will be carried out to see the linkages of the concept as well as it suitability with the determinant method of data validity in Islamic-based research methodology.

For carrying out the process, this paper will use content analysis method through the library studybased on common determination validity method and the mutawatir concept in 'Ilm al-Qira'at. Numerous references to be used either in the form of book, thesis, dissertations, working papers, and journals. Through these analysis, the purposes and compliance of this research can be carried out

For further discussion in this paper, this paper is divided into four parts. First, the types of the determinant method of data validity in common research methodology; Second, the history of "Ilm al-Qira'at; third, interest of mutawatir concept in determining of the authenticity of qiraat; and fourth, the mutawatir concept as a determinant method of data validity in research methodolgy.

\section{Types of Determinant Method of data validity In Common Research Methodology}

According to common research methodology, to confirm the data, researchers need to examine cautiously the information in order to produce a conclusion backed up with strong evidence. Researchers need to collect a large amount of data, describing the data and documents on how they collect and can inspect them. In addition, researchers also need to identify a variety of causes, processes, properties, or mechanism in the evidence or the data collected. Next, they look for patterns of similarities and differences, aspects of the same and which are not similar. They organize various information, discussion, and evidence, assess the merits of competition, find a more genuine, valid, true, or qualify them to test whether the review is carried out in a fair and equitable or not (Neuman, 2007; Braun, 1988 \& Ismail, 2015).

While the validity of the research means truthful and validity also deal with questions of how social reality is measured through research have in common with research or theory which was built by researchers to understand the reality. In addition, the validity is also regarded as a bridge connecting between the constructs and data (Neuman, 2007).

To assess and determine a validity of data, there are several types of methods used in common research methodology. They are construct validity, criteria validity, practical validity, content validity, internal validity, external validity, ecological validity, statistics validity, concurrent validity, and surface validity (Braun, 1988; Weller \& Romney, 1990; Ismail, 2015 \& Neuman, 2007). 
Looking at the diversity of data validation methods found in the usual research methods, it is recognized that if a data is determined by its validity through these rules it must be known to its validity. However, Islam has had the rules of determining the validity of the data before the existence of the methods used today in scientific studies.

As Muslims and Muslim scientists, using an authority sources and comes from the root of Islam should prevail from other sources. This is because not quite suitable for studying something related to Islam, but the study retrieved from methods of non-Muslims. Furthermore, the Qur'an, Hadith, ijmak and qiyas would have made the main reference in all efforts in Islamic research based. Those Basic resources are the resources of knowledge recognized by Allah (Abdullah, 2009). In addition, Muslims should believe in things that are intangible (supernatural). This is contrary to the common research methodology that using the Western methodology of different glass eyes (tasawur) with tasawur Islam. Using common research methodology for the study of Islamic Affairs and Muslims, findings and summary of the research will not be accurate as supposed to be. This is because it was measured from Western value and ideal (Salleh, 2010).

Therefore, this paper brings a method to be applied in the Islamic scholarly research which method of determinant data validity that uses one of the elements in 'Ilm al-Qira'at, namely mutawatir concept.

\section{The History of 'Ilm al-Qira'at}

Prior to deepen the meaning of the concept of mutawatir, first we need to know a little history and all-round development of one of the sources of Islam which is the 'Ilm al-Qira'at (science of recitation).

The original word for qira'at is from Arabic which means recitations. Qira'at is a plural word that show more than one recitation in specific ayah. The definition of the qira'at scholars, qira'at has several meanings such as the led meaning readings dedicated to the Qur'an as the qira'at of Ibn Mas'ud ra. In a clearer way, the meaning of qira'at is a recitation dedicated to a qira'at scholar only and anything that narrated from the scholar on ways the recitation of the Quran alleged is the recitation (qira'at) of the scholar. While 'Ilm al-Qira'at is a knowledge which introduced the ways of recitation ayah al-Qur'an with intermediate by talaqqi and al-musyafahah according to the narrated from qurra' (people who are experts in the field of qira'at) either agreed or disagreed to the recitation such recitation return reading to its narrator (al-Abidi, 2009).

Topics discussed in this 'Ilm al-Qira'at is the same as in 'ilm tajwid namely concerning of ayah of the Qur'an. While the purpose of learning this 'Ilm al-Qira'at is to take care of the Qur'an from fraud and to learn forms of qira'at revealed to Prophet Muhammad (PBUH). In addition, the aim is also to differentiate between authentic qira'at with unauthentic qira'at. Furthermore, learning this knowledge is fard 'ain to all Muslims. Is meant by learning this knowledge is by studying one qira'at of qira'at mutawatirat rather than study all kinds of qira'at. As for distinguishing between 'Ilm al- 
Qira'at with 'ilm tajwid is the 'Ilm al-Qira'at discusses about ways to recite ( $a d a^{\prime}$ ) al-Qur'an, while 'ilm tajwid discussing on how to recite and read letters of the al-Qur'an (al-Abidi, 2009).

When referred to 'IIm al-Qira'at, it connection with the recitation of the Qur'an al-Karim. 'IIm al-Qira'at started in when the first revelation to the Prophet (PBUH) with Jibril using talaqqi method (al-Sobuni, 1985; al-Jazari, 2004). Gabriel teach Rasulullah (PBUH) a number of verses each time revelation was revealed and Jibril reading the verses to the Prophet (PBUH) with certain methods to ensure that the Qur'an can be read by all Arab and Muslim generally, thus keeping the difference education in the Muslim community. The differences in reading the Qur'an is very clear and that indicates that these differences are tawqifi which means comes from God and not ijtihad of the Prophet (PBUH) or his companions. The difference in the reading is very closely related to the ahruf $s a b$ 'ah revealed to the Prophet (PBUH) to facilitate this Ummah and celebrating diversity Arab dialect at that time (al-Abidi, 2009). Narrated in a Hadith (al-Bukhari, 1986) that the dispute ever occurred between Saidina Umar al-Khattab ra and Saidina Hisyam ra about the difference this reading:

"Al-Bukhari and Muslim narrating (lafz from al-Bukhari) that Umar bin alKhatab said: I heard Hisyam bin Hakim read surah al-Furqan during the lifetime of the Prophet (PBUH), then I listen to his recitation (intentionally). Suddenly he read it with plenty of ahruf (i.e. with various qira'at) that does not recite to me by the Prophet (PBUH). I almost wanted to pounce on him in prayer but I wait until he gives salam (finishes prayer). Thus, I'm pulling his coat and said: "who taught you this surah?". He said: "the Messenger of Allah (PBUH) taught me". I said to him: "You lied. For God's sake that the Prophet (PBUH) have read this surah to me (i.e. his reading different reading heard from Hisyam) ". Then I took him to meet the Prophet (PBUH) and said: "Ya Rasulallah, I heard this (Hisyam) read surah al-Furqan with the recitation of which you do not read to me, and you have read al-Furqan to me". Said the Prophet (PBUH): "Release him, o Umar. Read o Hisyam". So Hisham read the sura with the recitation I heard just a moment ago. Said the Prophet (PBUH): "Thus it is revealed". Then the Prophet (PBUH) continue his word: "Indeed, alQura' $n$ is written down with seven letters (sab'ah ahruf), then recite a simple thereof". (Hadith narrated by al-Bukhari, Hadith No. 514).

Prophetic (PBUH) teaching his companions as taught by Gabriel to him (PBUH) from all ways, namely way method of reciting the Qur'an. In the Qur'an mentions that:

"It is a Quran We have revealed in stages so that you may recite it to people at a deliberate pace. And we have sent it down in successive revelations. " (alIsra', 17:106)

The companions after Rasululah (PBUH) recite the Qur'an with various recitations as taught by the Prophet (PBUH) with the difference of ahruf sab'ah. The most famous Qurra' in this era is are 
four khulafa' al-rasyidin; Abu Bakr Al-Siddiq, Umar bin al-Khattab, Uthman Ibn Affan, and Ali Ibn Abi Talib; Abdullah bin Abbas, Abdullah bin Mas'ud, Ubay Ibn Ka'ab, Zayd Ibn Thabit, Salim Mawla Abi Huzaifah and Muadh bin Jabal. This stage can be considered as the starting point the advent of qira'at's art in Islam from the point of implementation (al-'Abidi, 2006 \& 2009).

The difference of qira'at increasing significantly during the reign of Caliph Uthman bin Affan during which many people besides the Arab nation to convert to Islam in cities opened by the Muslim army like Armenia and Azerbaijan. Thus, Uthman bin ' Affan ordered to compiled the Qur'an in one mashaf. The Mashaf just placed texts presented to the Prophet (PBUH) at the last minute of his life (PBUH), put the verse that narrated in mutawatir alone and ignored revelations of the Qur'an which narrated in ahad and isolated also descriptions (tafsir) of the companions. Once from the Qur'an out of all of that, Uthman bin ' Affan ordered to be sent to the Muslim capitals at that time. The Mashafmashaf that transmitted contains qira'at- qira'at mutawatirat from Rasulullah SAW. The Mashaf has no dots and rows to facilitate qari (person who recite al-Qur'an) to recites with a variety of qira'at mutawatirat (al-'Abidi, 2006).

Thus, the history of 'Ilm al-Qira'at is briefly as an overview of the beginning of the emergence of this knowledge so that the development of this knowledge in all Islamic cities. Looking at the rapid development of this knowledge beginning in the first century until the eighth century, it is found that this 'Ilm al-Qira'at is one of the most important knowledge in Islam. This is because the connection of 'Ilm al-Qira'at directly to the Qur'an causes many Islamic scholars to explore this knowledge such as Imam Al-Sallam, Imam Ibn Mujahid, Imam Ibn Khaluyah, Imam Ibn Jazari, Imam al-Syatibi and many more. Therefore, this study is trying to pursue this knowledge for taking and extract the essence contained within it that can be applied in the current knowledge so that the knowledge of Islam is not just in the room alone.

\section{Mutawatir's Importance in Determining the Authenticity of a Qiraat}

Based on the history of 'Ilm al-Qira'at, it is found that the Muslims started in the time of the Prophet Muhammad until the 3rd century Hijra very much emphasized this Qiraat Science. This can be seen by the development of this knowledge with the rise of qurra' scholars. Even qira'at- qira'at is maintained and evolved in every Muslim city by increasing and expanding qurra' scholars for every qira'at.

Next 3rd century Hijrah is a period that separates the authentic (qira'at sahihah) qira'at and qira'at syadhdhat. This separation is performed by Imam Ibn Mujahid. Imam Ibn Mujahid has laid down some conditions (dawabit) in knowing the dignity of a qira'at. Imam Ibn Mujahid could be regarded as the first person to put the dawabit in 'Ilm al-Qira'at. The dawabit is:

1. A person who is considered an expert in qira'at. This person who is recognized his knowledge by his people. For example, qurra' for qira'at sab'at.

2. A person who studies specifically the 'Ilm al-Qira'at and 'alim (an expert) in the field of Nahu (Arabic grammar) (al-'Abidi, 2006 \& 2009). 
To more clarify the dawabit set by Imam Ibn Mujahid, this is illustrated in Diagram 1.

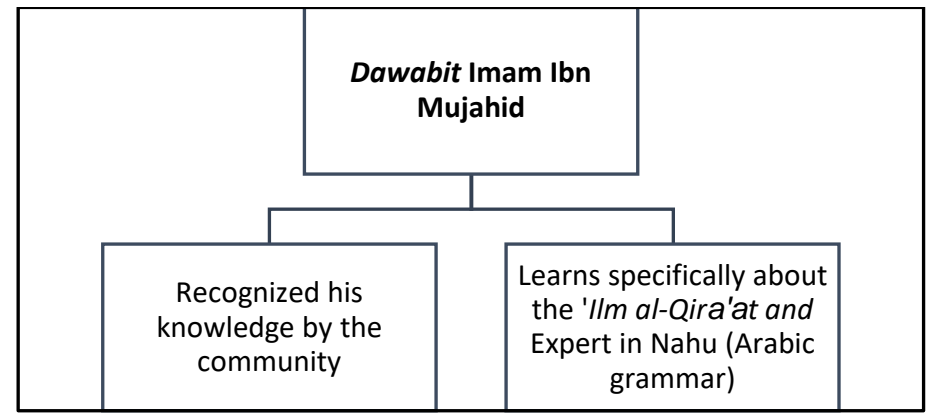

Diagram 1: Dawabit Imam Ibn Mujahid

After Imam Ibn Mujahid placed these two dawabit, came Imam Ibn Khaluyah, student of Imam Ibn Mujahid who placed another measurements. Imam Ibn Khaluyah placed three conditions in order to allow a qira'at to be accepted or rejected. The three conditions are:

a) A qira'at must conform and fit to Rasm Mashaf Uthmani.

b) Must conform to the Arabic method (grammar).

c) The sanad should be continued (al-'Abidi, 2006) or the narration of a qira'at shall mutawatir (Syalabi, 1999).

To give a clearer picture, this is illustrated in Diagram 2.

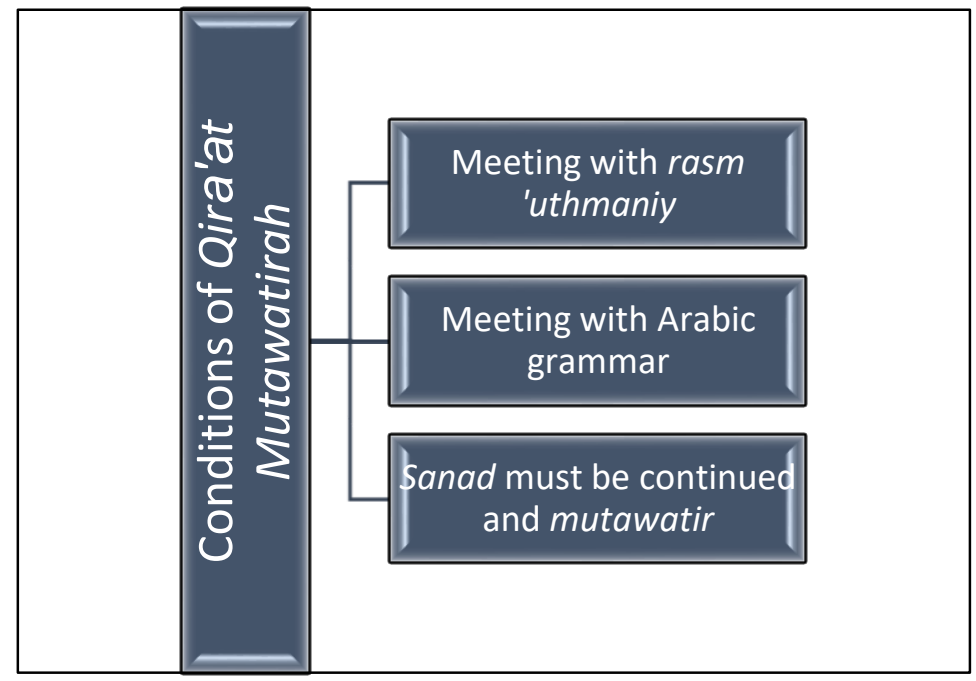

Diagram 2: Three Conditions of Qira'at Mutawatirah

Mutawatir or al-tawatur means a group of narrators (rawi) from a generation that it is impossible for them to commit a whisper has narrated a qira'at from a group of narrators from the previous generation, and this process proceeds until the first chain which is to the Prophet (PBUH) 
INTERNATIONAL JOURNAL OF ACADEMIC RESEARCH IN BUSINESS AND SOCIAL SCIENCES Vol. 8, No. 10, Oct. 2018, E-ISSN: 2222-6990 @ 2018 HRMARS

(Syalabi, 1999) through the method of al-Sama' and al-Musyafahat (al-'Abidi, 2006; Sulaiman, 2013). When a qira'at does not meet one of these conditions, the qira'at is supposed to be rejected (mardudah) and is not considered as a Qur'anic verse even it is not legally recited in the prayer.

Upon seeing and examining the valid qira'at terms and mutawatir definitions, the strength of the mutawatir concept and components within it can be taken to be one of the strengths of the validation of a data. The components are the first, the connected sanad (called mutawatir) and the second is al-Sama 'and al-Musyafahat. Both of these components will be explained in the next topic.

\section{Mutawatir Concept as a Method of Determinant Data Validity of Research}

Having identified the essential components of the 'Ilm al-Qira'at, the explanation of each component is necessary to further explain the importance and usefulness of these components beyond the usual scope of use.

First is the connected sanad (mutawatir). There are several elements that require the validation of sanad and mutawatir, which is the number of narrators and the characteristics of each narrator. The number of narrators at each stage or generation should be sufficient to incapable of being accused of agreeing to lie to any information. While the characteristics of the narrator is that a narrator should be known for the attribute of the memory (dabit), the trust, was in the long run in studying and practicing qira'at, and agreeing the scholars in the necessity of learning with the narrator and talaqqi (taking knowledge face to face) from him (al-Sabuni, 1985). In addition to the above attributes, a narrator must also be fair ('adl), understanding, and Muslim (Ibn Jazari, 2014; alSuyuti, t. t \& Salih, 1993). This can be seen in Diagram 3.

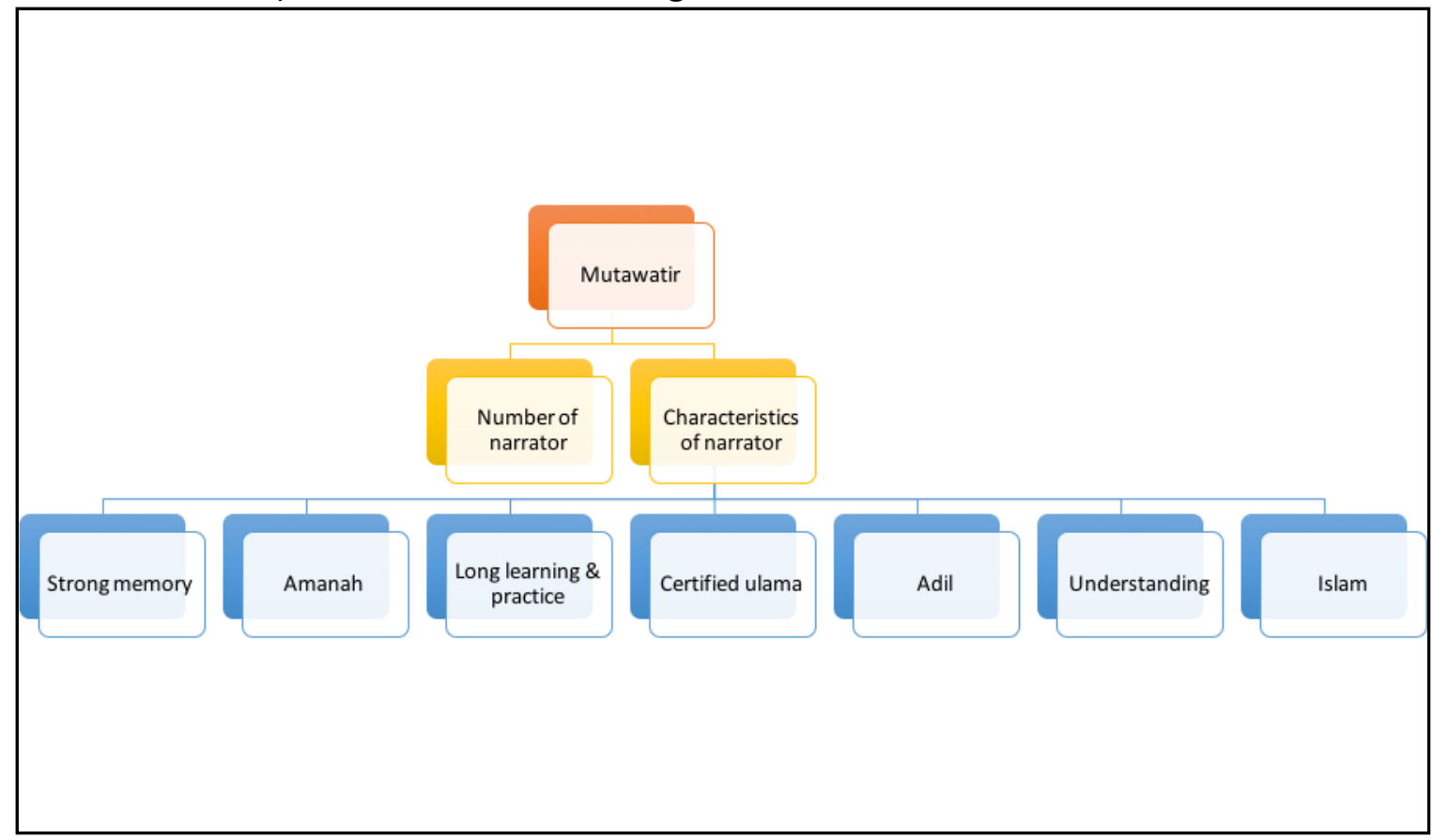

Diagram 3: Elements of Mutawatir Concept 
Looking at the method of determining the validity of the data in the research method, A large number of respondents are important to ensure that the collected data is appropriate and does not conflict with each other. In contrast to the data taken from a single respondent there is likely to be data that cannot be confirmed legally. While the characteristics that need to be present in the respondents are important to strengthen the data and respondents' choice is not random.

The second component is al-Sama' and al-Musyafahah. In the 'Ilm al-Qira'at, to ensure that a qira'at is authentic, it is necessary to study the qira'at narration whether the narrator takes the qira'at by listening and reading directly in front of his teacher or not. When it is ascertained that the narrator is reading in front of his teacher and listening directly, then the qira'at is supposed to be authentic and can be appointed as one of the recitation of the Qur'an. This method is also called talaqqi.

If applied the method of al-Sama' and al-Musyafahah in this 'Ilm al-Qira'at to research method specially to determine the validity of a data, it is certain that the data becomes stronger and believed to be its authenticity. This is because data are obtained directly from the source and are believed to be based on the characteristics inherent in the respondent is a strong and undeniable data of its authenticity.

After being reviewed and discussed, all of these components and elements can be collected in a specific concept, the concept is called the mutawatir concept. This mutawatir concept is seen as used in the current research method as one of the determinant methods of data validity for research methods.

\section{Conclusion}

Based on previous discussions, it is found that the method of determinant data validity can be derived from traditional Islamic knowledges such as the 'Ilm al-Qira'at. Concept mutawatir has enough elements in shaping one of the authentication methods research data related to Islam and Muslims, especially in setting up a new research method which research methods based on Islam. Through this mutawatir concept, the data becomes stronger and is believed to be the source. Therefore, it is advisable for the Muslim scholars to further explore and fine-tune the Islamic traditional knowledges so that the knowledge not only linger in the Islamic study space but also to penetrate all other knowledge as had been done by previous Muslim scholars. Although there are not much discussions on the application of Islamic knowledges in Islamic-based research methods, it is hoped that this study will be one of the new dimensions of the Muslim ummah to further develop Islamic knowledge that has long been established in Islam.

\section{Acknowledgement}

Special appreciations to the Research Management, Innovation \& Commercialization (RMIC), Universiti Sultan Zainal Abidin (UniSZA) \& the Faculty of Islamic Contemporary Studies (FKI, UniSZA) for sponsoring the project. 
INTERNATIONAL JOURNAL OF ACADEMIC RESEARCH IN BUSINESS AND SOCIAL SCIENCES

Vol. 8, No. 10, Oct. 2018, E-ISSN: 2222-6990 ㄷ 2018 HRMARS

\section{Corresponding Author}

Nur Sakiinah binti Ab Aziz, Faculty of Islamic Contemporary Studies, Universiti Sultan Zainal Abidin (UniSZA), 21300 Kuala Terengganu, Terengganu. Email: sakiinahaziz@unisza.edu.my

\section{References}

Syalabi, A. F. I. (1999). Al-Madkhal wa al-Tamhid fi 'Ilm Al-Qira'at wa al-Tajwid. Kaherah, Mesir: Maktabah Wahbah.

Airasian, G. (2003). Educational Research; Competencies for analysis and applications. New Jersey: Pearson Education.

Abdullah, A. (2009). Panduan Pemakaian Sumber-Sumber Asas Kajian (Al-Quran, Al-Hafith, ljma' dan Qiyas). Paper presented at the Penyeliaan Bulanan Siswazah, Universiti Sains Malaysia.

Berg, B. L. (2007). Qualitative Research Methods for the Social Sciences. United State of America: Pearson Education, Inc.

Braun, H. W. H. I. (1988). Test Validity. Hillsdale, New Jersey: Lawrence Erlbaum Associates.

Al-Bukhari. (1986). Sahih al-Bukhari. Pakistan: Matba'ah al-Maktabah al-'Ilmiah.

Al-'Abidi, F. (2006). Al-Jam' bi al-Qira'at al-Mutawatirat. Beirut, Lubnan: Dar Ibn Jazm.

Al-Abidi, F. (2009). Kulliyyat al-Tajwid wa al-Qira'at (Jam' wa Siyanat wa Syarh). Beirut, Lubnan: Dar Ibn Hazm.

Ibnal-Jazari, (2004). Taqrib al-Nasyr fi al-Qira'at al-'Asyr. Kaherah, Mesir: Dar al-Hadis.

Ibnal-Jazari, (2014). Al-Nasyr fi al-Qira'at al-'Asyr. Kaherah, Mesir: Maktabah al-Sofa.

Al-Hafiz, I. M. (t.t.). Ilmu Qira'atul Quran. Kuala Lumpur: Syarikat Nurulhas.

Al-Suyuti, J. (1960). Al-Itqan Fi 'Ulum Al-Qur'an: Dar Al-Fikr.

Al-Sobuni, M. A. (1985). Al-Tibyan fi 'Ulum al-Qur'an. Beirut, Lubnan: Alam al-Kitab.

Salleh, M. S. (2010). Kaedah Penyelidikan Berteraskan Islam; Keperluan, Kedudukan dan Hala Tuju. Pemikir, 54, 133-164.

Neuman, W. L. (2007). Basics of Social Research: Qualitative and Quantitative Approaches. United State Of America: Pearson Education, Inc.

Ahmad, R. (2000). Introduction to al-Hadith. India: Adam Publishers \& Distributors.

Ismail, R. (2015). Metodologi Pendidikan; Teori dan Praktis. Bangi, Selangor: Penerbit Universiti Kebangsaan Malaysia.

Romney, S. C. W. A. K. (1990). Systematic Data Collection. Newbury Park, California: SAGE Publications, Inc.

Sulaiman, S. (2013). Al-Qiraat Al-Mutawatirah dan Kesannya Terhadap Pentafsiran Al-Quran: Kajian terhadap kitab Marah Labid Li Kashf Ma'na Al-Quran Al-Majid karangan Nawawi Al-Bantani Tumpuan Terhadap Surah al-Baqarah. (Ph.D), Universiti Malaya, Kuala Lumpur. 